\title{
Speed of China's OFDIs to the Belt and Road Initiative destinations: State equity, industry competition, and the moderating effects of the policy
}

\author{
Bin Liu ${ }^{1}$ () and Qingtao Wang ${ }^{2}$ \\ ${ }^{1}$ Department of Business Management, School of \\ Management, Xiamen University, Xiamen, China; \\ ${ }^{2}$ Department of Marketing, School of Business \\ Administration, Faculty of Business \\ Administration, Southwestern University of \\ Finance and Economics, Chengdu, China \\ Correspondence: \\ Q Wang, Department of Marketing, School \\ of Business Administration, Faculty of \\ Business Administration, Southwestern \\ University of Finance and Economics, \\ Chengdu, China \\ e-mail: wangqt@swufe.edu.cn
}

\begin{abstract}
Organizational timely investments determine the success of the Belt and Road Initiative (BRI), yet few studies have explored the antecedents of those speed decisions. Based on a dataset of Chinese-listed firms over 11 years, we address this research paucity by incorporating the push and pull antecedents of OFDIs. The study revealed that industry competition significantly facilitates organizational BRI investment speed after the launch of the initiative, but such facilitative effects become weaker for firms located in the key BRIparticipating provinces. Intriguingly, firms with greater state equity are slow after the launch of the BRI, and their slow gestures become more severe in those key provinces. The additional tests implicated that this result occurs because of inadequate positioning of those inland provinces. Overall, the study clarified the nature of the BRI by exploring the speed dimension. The findings also challenged the conventional wisdom of treating firms with greater state equity as obedient extensions of the government by unmasking their conservative attitudes toward the BRI, highlighting some fallacies of contemporary BRI policy. Third, the temporal and geographic aspects should be applied simultaneously to examine the policy effects of the BRI.
\end{abstract}

Journal of International Business Policy (2022) 5, 21 8-235.

https://doi.org/ | 0.1057/s422 I 4-021 -00 I 25-6

Keywords: Belt and Road Initiative; speed of OFDIs; state equity; industry competition; temporal and geographic aspects

\section{INTRODUCTION}

What does the Belt and Road Initiative (BRI) mean for business entities? Unveiled in 2013, the BRI intends to help the Eurasian economy prosper while helping resolve excessive production capacity via intense government-led investments (Li et al., 2019b; Li, Van Assche, Li, \& Qian, 2021a). Although the initiative introduces substantial risks since most destinations are politically and institutionally unstable (Gurin, How, Jackson, \& Yu, 2015), the BRI is advocated as a policy cure for international business (IB) (Buckley, 2020; Van Assche \& Lundan, 2020), particularly under
Received: 14 February 2020

Revised: 1 September 2021

Accepted: 15 October 2021

Online publication date: 6 January 2022 
the recent sentiments of protectionism and deglobalization (Wang \& Liu, 2021).

While progress has been made on the effects of the BRI on the international scale and scope of private enterprises (e.g., Li et al., 2019b; Wang \& Liu, 2021), the literature remains surprisingly silent on the speed dimension of outward foreign direct investments (OFDIs) (Chang \& Rhee, 2011; Yang et al., 2017). In addition to its influences on organizational global competitive position (Gaba et al., 2002; Tang, 2019), the speed of OFDIs, captured by the number of accumulated new OFDIs divided by the number of years since year 0 (Chang \& Rhee, 2011; Vermeulen \& Barkema, 2002; Yang et al., 2017), has distinct meaning for the BRI in that timely investments are the preconditions of the establishments of new trading relationships (Belt \& Road Portal, 2017). Moreover, faster investments from private firms could increase general confidence in the BRI because many may perceive the initiative as a game for state-owned enterprises (SOEs) only (Wang \& Liu, 2021), particularly under fierce Sino-US geopolitical contests ( $\mathrm{Li}$ et al., 2021a). Faster investments from private firms thus help build an entrepreneurial ecosystem that fosters sustainable economic prosperity ( $\mathrm{Li}$ et al., $2019 b)$, although SOEs are undeniably key players in BRI projects (Li et al., 2021a).

As such, this study explores whether and how the BRI has incentivized Chinese private firms to accelerate internationalization to BRI destinations because China is the initiator and a key player of the BRI. Examining speed issues can help unmask whether and how the BRI achieved its policy expectations while responding to calls for further understanding the facilitators of burgeoning investments from emerging economies (Luo \& Wang, 2012; Van Assche, 2018; Wang Jiang, \& Dong, 2021). After all, emerging economies are the key players under the BRI blueprint (Wang \& Liu, 2021), which are economies with weak institutions and unequal regional developments but unpredictable economic growth (Qian Liu, \& Wang, 2018). Such an examination is also policy-relevant, as studying the speed of internationalization across firm types and industries helps clarify the nature of the BRI.

To address this lack of research, we investigated both the push and pull antecedents of OFDIs under the BRI theme. Specifically, we examined state equity and industry competition as potential drivers of the speed of OFDIs to BRI destinations because firms' internal resources and external competitive environments are two disparate forces that might affect internationalization speed (Chang \& Rhee, 2011; Gaba et al., 2002). Given that the Chinese government has conferred special roles and support to different provinces (Belt \& Road Portal, 2020), we further explored the geographic aspect of the policy effects by examining whether the differences become stronger for firms located in those planned key BRI-participating provinces.

To test the hypotheses, we tracked a sample of Chinese-listed firms' BRI investments between 2009 and 2019, which are extracted from the Chinese Stock Market Accounting Research (CSMAR) database. We found that industry competition significantly facilitates the organizational speed of BRI investments after the launch of the initiative, but such a facilitative effect becomes weaker for firms located in those key BRI-participating provinces. Contrary to our hypotheses, however, firms with greater state equity tend to be slower in making such investments after the launch of the BRI, and their slow gestures become more severe when they are located in those key provinces. Our additional tests helped disentangle intriguing geographic heterogeneities. For instance, many of those key BRI-participating provinces are poor in economic endowments, and local firms lack the competencies to serve the target foreign markets. We further speculated that the slow speed of investment among firms with greater state equity is caused mainly by their prudence, as they perceive favorable conditions in domestic markets, albeit firms dominated by the state may be pushed to expand more rapidly. Together, these results imply that Chinese firms generally hold conservative attitudes toward BRI markets and invest along the routes only if the home markets are unfavorable.

The study thus makes three major contributions. First, we helped address the scarcity of research on speed issues while challenging the traditional narrative of the BRI. Responding to calls for more examinations of the distinct characteristics of OFDIs from emerging economies (Luo \& Wang, 2012; Van Assche, 2018), we advanced knowledge about the drivers of the speed of OFDIs by recognizing both the push and pull factors under the BRI theme. Moreover, we cautioned that the policy effects of the BRI should be judged from multiple dimensions and that private firms are among the speediest investors, particularly in competitive industries. This finding presents direct evidence that challenges the traditional narrative of the BRI as an example of state capitalism. Second, we 
challenged the conventional wisdom of state equity. While prior literature has postulated that state equity helps create a unique international competitive advantage in realizing governments' political agenda (Buckley et al., 2007; Qian et al., 2018), we unveiled that firms with greater state equity are conservative in terms of the risks of quickly investing along BRI routes even in the absence of legitimacy concerns, contrary to the expectations of the Chinese government. In other words, escapism (i.e., pull effect) is the main mechanism that explains OFDIs under the BRI theme, which highlights some fallacies of contemporary BRI policy. Third, we presented new angles to test the policy effects of the BRI. In contrast to pioneering studies that emphasize whether BRIrelated subsidies boost exporting (Li et al., 2019b) or whether OFDIs rose significantly after the launch of the BRI (Du \& Zhang, 2018), we have introduced both the temporal and geographic aspects of the BRI. That is, we cautioned that the BRI takes effect only if those key influencers derived from the policy blueprint show significant differences across the time and the region when and where the policy has been launched. Surprisingly, however, we found that firms located in those planned key BRI-participating provinces exhibit slower speed, which reminds policy-makers of the subnational differences and positioning of those provinces.

The remainder of the article starts with a brief introduction to the BRI and a literature review of how the push and pull factors of OFDIs might influence the speed of entry into another country. We then hypothesize how the state equity and industry competition derived from the BRI blueprint might influence speed decisions moderated by the policy. After elaborating on the method, both contributions and limitations are discussed.

\section{LITERATURE REVIEW AND HYPOTHESIS DEVELOPMENT}

\section{BRI: Opportunities and Risks}

Reborn from the heritage of ancient silk trade, the BRI was inaugurated during the president of China's state visit to Kazakhstan and Indonesia in 2013 when calling for deeper multilateral cooperation and interactions (Belt \& Road Portal, 2017). Led by China, the BRI aims to establish new transportation and economic corridors linking Europe and Asia through the Middle East, Central Asia, and the South China Sea, known as the Silk
Road Economic Belt (the belt) and the New Maritime Silk Road (the road) (Belt \& Road Portal, 2017; Li et al., 2019b). It is expected that excessive production capacity can be resolved under new economic prosperity if those BRI destinations are provided with intensive government investments (Li et al., 2019b). To date, 140 countries have officially joined this magnificent plan, and 18 provinces in China have been designated as key players referring to their historical, geographical, and economic positions, which are supported with special funds and policy treatments (Belt \& Road Portal, 2020).

However, private firms are exposed to risks caused by the poor institutional conditions of BRI countries. Specifically, most BRI destinations suffer from frequent regime changes and threats of terrorism (Gurin et al., 2015); thus, investors may feel helpless in commercial disputes and even lose their property and lives. Under these circumstances, home governmental support becomes a necessary precondition for international venturing along routes (Wang \& Liu, 2021), although most of those countries are characterized by substantial growth potential (Li et al., 2019b).

Such entanglement of unique opportunities and risks demands organizational careful calculations of the contingencies. Therefore, private firms may exhibit idiosyncratic attitudes toward the BRI, referring to their capabilities to capitalize on the policy and characteristics of the surrounding environments. Moving beyond preliminary descriptions (e.g., Gurin et al., 2015), studies have started recognizing such organizational heterogeneities under the BRI theme. For instance, Li et al. and his associates (2019b) suggest that SMEs participate in the BRI if given significant government subsidies. Wang and Liu (2021) further argue that firms with more state equity would confront more political pressure to invest heavily along the BRI routes.

While these researchers present insightful discussions about the heterogeneity of the internationalization scale and scope under the BRI theme, they offer limited knowledge about speed (Chang \& Rhee, 2011; Yang et al., 2017), which is another important dimension of IB decisions (Gaba et al., 2002; Tang, 2019; Vermeulen \& Barkema, 2002). In fact, speed of entry is a critical benchmark for policy-makers to evaluate the effects and efficacies of the BRI policy (Van Assche, 2018), as faster organizational expansions suggest greater confidence. Against this backdrop, we require a systematic examination of what factors trigger faster 
organizational participation in the BRI, which is meaningful in terms of both policy and theory.

\section{Literature Review of the Speed of Internationalization}

The IB literature used to pay much attention to the liabilities of foreignness when discussing international expansion into foreign markets (Qian et al., 2013). Defined as disadvantages caused by nonnative status (Johanson \& Vahle, 2009), prior studies have argued that foreign investments start from areas with cultural and geographical proximity because of easier communication and understanding (Buckley et al., 2007). However, this situation may not be the case for firms from emerging economies.

Specifically, it has been posited that governmental support and industry hardship constitute the push and pull factors that make OFDIs from emerging economies deviate from the sequential mode. On the one hand, the governments of emerging economies provide financial support and favorable policies to encourage firms to expand internationally (Gaur et al., 2018; Wang \& Liu, 2021), with the aim of acquiring strategic assets that can help sustain domestic economic growth and seizing opportunities to establish global competitiveness (Qian et al., 2018; Tang, 2019). On the other hand, firms might be pulled away by other undefended markets to avoid fierce competition in home countries (Luo \& Wang, 2012).

However, few studies have applied these two disparate forces to the speed decisions of OFDIs from emerging economies, although the literature agrees that organizational internal resources and external competitive environments might affect the speed of international expansions (Chang \& Rhee, 2011; Gaba et al., 2002). After all, speed and sequence are two independent dimensions such that rapid expansions can be sequential or not (Chang \& Rhee, 2011). One exception was conducted by Gaba et al. (2002), who proposed that organizational factors such as international experience, firm size, and attributes of the hosting country manifested by industry growth and country risks together affected American firms' speed of entrance into China when China opened its market. However, their research context is less helpful for capturing the current transitions in the OFDI landscape, as most equity now initiates from emerging economies (Lebedev et al., 2015; Luo \& Wang, 2012). Although recent studies have started to redress this lack of research, most of those initiatives suffer from different incompleteness issues. For instance, Chang and Rhee (2011) emphasized how the speed of OFDIs affects organizational performance. Tang (2019) directly examined how state socialism logic affects the speed of OFDIs, yet he did not consider the pulling effects of industry competition.

Moreover, the examination of governmental support and industry hardship lends unique meaning to the understanding of the BRI. Echoing the two dimensions, the BRI makes governmental support an explicit instrument to incentivize OFDIs across BRI countries, with the intention of boosting economic growth that can consume excessive production capacity (Li et al., 2019b). Therefore, examinations of the two disparate forces could not only supplement the research dearth in speed issues of OFDIs from emerging economies but also help unveil whether and how the BRI has achieved its policy expectations. If no sharp difference was identified with and without the BRI policy, it is difficult to conclude that the BRI generates any significant policy effects because China had similar outward-oriented policies in the past. If the BRI took effect, the differences between the two forces could further indicate whether support or escapism helps the BRI achieve its policy expectations. Notably, the policy effects can be manifested in both temporal and geographic dimensions such that the effects of the two forces should differ when comparing firms before and after 2013 and those within and outside the key BRI-participating provinces (Belt \& Road Portal, 2020).

\section{Hypothesis Development}

Governmental support functions as the key pushing factor of OFDIs from emerging economies. To sustain domestic economic developments (Qian et al., 2018), governments tend to provide financial resources and favorable policies to push firms to expand internationally to acquire strategic assets and establish global competitiveness (Qian et al., 2018; Tang, 2019). Because state equity functions as the most legitimate and formal means for private firms to connect with governments (Li et al., 2021b; Qian et al., 2018), a higher level of state equity should suggest a larger organizational amount of governmental support and a greater extent of interest alignments with the political agenda (Wang \& Liu, 2021; Wang, Xie \& Wang, 2015).

Such support should substantially allay concerns over the risks and uncertainties of foreign market expansions to accelerate the speed of OFDIs. That 
is, private firms are less likely to be deterred by the disadvantages of nonnative status because governmental support provides firms with more resources for trial and error (Gaur et al., 2018). Therefore, firms become both confident and capable of conducting rapid OFDIs that might help them reap higher profits (Chang \& Rhee, 2011). Although such facilitative effects seem to be sustained all the time, we posit that firms with greater state equity should play a more important role in speeding up OFDIs to BRI destinations, particularly after the launch of the BRI.

First, the launch of the BRI makes rapid OFDIs to BRI destinations a political task that must be performed among firms with greater state equity. At the kernel, firms with greater state equity face greater political pressure as the equity structure increases the binding and interactions (Qian et al., 2018) and indoctrinates governmental logic into the focal firm (Greve \& Zhang, 2017). Under these circumstances, it is highly likely that the government serves as a critical client and/or investor and arranges more bureaucrats into key managerial positions (Zhou et al., 2017). Therefore, those firms would strive to favor the government through responsive actions because of the dependent relationship and ideological control (Wang \& Liu, 2021). Given that the BRI is a government-led project (Li et al., 2019b), firms with greater state equity should feel stronger obligations to be early movers in investing along the routes.

Second, the launch of the BRI makes OFDIs to BRI destinations an attractive task for firms with greater state equity. While governments generally encourage firms to expand internationally (Gaur et al., 2018), firms with greater state equity may not be able to achieve their global ambition, as host countries may perceive them as governmental extensions, thus challenging their authenticity and legitimacy in doing business (Tang, 2019). However, the BRI calls for substantial state involvement (Li et al., 2019b), and participating countries have agreed to establish favorable policies to facilitate government-led cooperation (Wang \& Liu, 2021). Therefore, legitimacy concerns become less critical, particularly after the launch of the BRI.

In parallel, a faster expansion can help firms with greater state equity be better recognized by the governments, thus gaining legitimate status to receive more governmental support because most BRI destinations are new to everyone (Li et al., $2019 b)$. With this support, they should possess stronger capabilities to compensate for the institutional scarcity of resources and political instability that characterize most destinations along the BRI routes. Taken together, firms with greater state equity should have the obligation, desires, and capabilities to expand along the BRI routes quickly. Therefore,

Hypothesis 1: Firms with greater state equity invest in BRI destinations more quickly after the launch of the BRI.

In parallel, favorable market conditions abroad serve as the key pulling factor of OFDIs from emerging economies. Such favorableness is primarily justified by the extent of industry competition because a less competitive industry would allow more profits and growth potential (Luo \& Wang, 2012). Given that competition is largely bounded countrywide (Yang et al., 2017), the escalation of domestic industry competition might motivate firms to expand abroad to escape from the difficulties in earning profits and obtain access to strategic resources that can be used for domestic competition (Gaur et al., 2018; Luo \& Wang, 2012). Essentially, external industry attributes determine organizational strategies and thus competitive advantages (Gao et al., 2010; Peng et al., 2008; Porter, 1980).

We conceive that industry competition would trigger faster expansions along the BRI routes, particularly after the launch of the initiative. Fierce competition could put organizational survival at risk, thus incentivizing firms to explore new market fronts (Porter, 1980). While firms may previously have enjoyed a variety of alternative destinations to choose from, most developed economies have gradually lost their attractiveness because of their decelerated growth momentum since the 2008 world financial crisis and recent sentiments of protectionism (Wang \& Liu, 2021). In contrast, quick expansions to undefended BRI countries have become a viable strategy because those markets lend opportunities for low-ended products, thus helping prevent head-on competition in the home country (Luo \& Wang, 2012), given that most Chinese firms (companies in other emerging economies as well) rely on cost-based advantages (Gaur et al., 2018).

However, significant accelerations would be evidenced, particularly after the launch of the BRI. First, the launch of the BRI attracts attention to invest in BRI destinations. Business owners and managers used to focus on developed countries 
such as Japan, the United States, and Germany, which constitute the top trading partners of China (World Bank, 2012). As few companies had a substantial footprint in the BRI areas in the past, firms do not have many competitors to learn from and refer to. However, the launch of the BRI introduces a series of acculturation interactions, such as exhibitions, student exchange programs, and similar engagements (Wang \& Liu, 2021), which provide firms with a good opportunity to learn about seemingly mysterious and exotic markets. Governments also intentionally establish role models of pioneering firms for propaganda, which can signal profitable opportunities and attract other firms to move faster (Gaba et al., 2002). This situation can occur because firms typically observe and follow the actions of competitors and fear that early movers would erect entry barriers for latecomers (Gao et al., 2010; Porter, 1980). Consequently, firms under greater industry competition would accelerate their OFDIs to BRI destinations, particularly after the launch of the BRI.

Second, the launch of the BRI marks the beginning of sharp market growth. In general, high domestic market competition drives firms to explore new markets abroad because the margin is too thin to be profitable (Gao et al., 2010; Gaur et al., 2018). While most BRI destinations suffered from considerable risks and uncertainties and were not on the radar of firms before (Gurin et al., 2015), the launch of the BRI reflects multilateral desires and joint efforts to facilitate economic development (Wang \& Liu, 2021). Such policy accomplishment should reduce organizational concerns and inspire firms to seize those new market potentials. After all, the broad geographic coverage and large population size of BRI countries suggest substantial consumer demands and abundant and cheap labor supplies (Du \& Zhang, 2018). Therefore, expanding into those markets provides a larger pool of customers and economies of scale in production, thus alleviating competitive pressure (Gaba et al., 2002; Gao et al., 2010).

Additionally, intensive competition in the home market trains firms to be skillful in cost management (Gao et al., 2010), which may provide them with competitive advantages in competing in BRI destinations after the launch of the BRI. Moreover, the opening of new market fronts marked by the launch of the BRI may also enable firms to obtain resources at a low cost to compete in the Chinese market, given that most of those markets are resource-intensive (Li et al., 2019b). In summary, the launch of the BRI should both inspire imitation behaviors and kindle new market growth, attracting firms to invest in BRI destinations more quickly to circumvent domestic industry hardship.

Hypothesis 2: Firms under greater industry competition invest in BRI destinations more quickly after the launch of the BRI.

Notably, the policy effect of the BRI varies across provinces as well. In emerging economies, subnational differences are prevalent because governments tend to concentrate on the development of some regions with their limited resources (Qian et al., 2018). With respect to the BRI, the Chinese government assigns different roles to different provinces according to their historical and geographical characteristics (Belt \& Road Portal, 2020; Chang, Torres de Oliveira, Chung, \& Zheng, forthcoming). That is, 18 provinces that are historically tied to and geographically close to either the "Belt" or the "Road" destinations are recognized policywise as key participants under the theme and are provided with special BRI funding and policy support. Such policy arrangements resonate well with the unequal regional institutional conditions that characterize emerging economies (Qian et al., 2018; Wang \& Liu, 2021; Wang Ma, \& Hu, 2018; Zhou et al., 2017), which might introduce additional heterogeneities to the organizational speed of OFDIs to BRI destinations.

Given that the BRI is heavily influenced by government policies and political instabilities (Gurin et al., 2015), we deem that firms with greater state equity and under greater industry competition should exhibit a faster speed of OFDIs if they are located in those planned key BRIparticipating provinces. Although the policy is initiated by the central government asking all levels of governments to provide needed support for the firms (Li et al., 2019b), those key BRIparticipating provinces would invest greater effort into fulfilling this political task, generating stronger policy effects. The latter would occur because these provinces' government bureaucrats strive to exceed the basic requirements and expectations to succeed in the so-called political tournament, i.e., the chances of being promoted (Wang \& Liu, 2021). Thus, those local governments pay particular attention to the BRI participation of firms with greater state equity, which are under their direct control. Under such close supervision, those firms located in those BRI-participating provinces would confront 
stronger political pressure in pursuing faster expansions.

Second, those local governments would also provide more policy backups and financial support for firms within their jurisdiction. On the one hand, provincial governments have obtained greater subsidies and support from the central government specifically for the BRI (Belt \& Road Portal, 2020), providing resource reserves and governmental discretion to support pioneering firms. Therefore, faster expansions into BRI countries become a more attractive task for firms with greater state equity.

Simultaneously, those provincial governments are provided with more resources (and flexibility) to propagandize the benefits of investing in BRI destinations, allowing them to send more positive signals to firms suffering from more severe industry competition. These conditions also enable them to provide additional governmental help in focal destinations, strengthen organizational capabilities to capitalize on market growth in focal destinations and seize resources, particularly for firms under greater industry competition. For instance, Gansu, one of the 18 provinces, has established business representative offices in nine BRI countries. As such, those planned key BRI-participating provinces would present greater policy effects, thus further accelerating the speed of OFDIs. Therefore,

Hypothesis 3a: Firms with greater state equity and located in a planned BRI-participating province invest in BRI destinations more quickly after the launch of the BRI compared to those that do not, ceteris paribus.

Hypothesis 3b: Firms under greater industry competition located in a planned BRI-participating province invest in BRI destinations more quickly after the launch of the BRI compared to those that do not, ceteris paribus.

The conceptual model is shown as below.

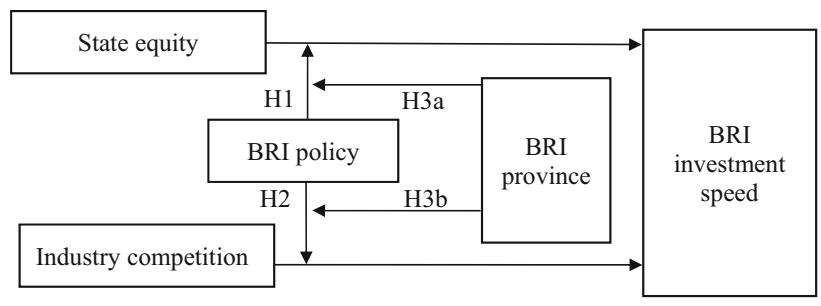

Figure 1 Conceptual model.
Table 1 Main steps of the sample selection

\begin{tabular}{lll}
\hline Step & Details & Num \\
\hline 1 & Initial sample & 3358 \\
2 & Exclusion of firms that are in the finance industry & -58 \\
3 & $\begin{array}{l}\text { Exclusion of firms without overseas investment } \\
\text { information }\end{array}$ & -1343 \\
& Final sample & 1957 \\
\hline
\end{tabular}

\section{METHODOLOGY}

\section{Sample}

To test our hypotheses, we used the China Stock Market Accounting Research database (CSMAR), which is a reliable data source for IB studies in China, to construct the sample (e.g., Li et al., 2019a; Wang \& Liu, 2021). We further merged firm information with additional data sources, including the China Statistical Yearbook and China's BRI official website (http://www.yidaiyilu.gov.cn/). We restricted our sampling time from 2009 to 2019 to capture the most updated BRI dynamics while circumventing the impact of the global financial crisis in 2008. Although the BRI certainly influences unlisted SMEs as well (Li et al., 2019b), we focused on publicly listed firms to ensure data validity and reliability. As Table 1 shows, we started with all the listed firms in this sampling period, then excluded firms in the finance industry and deleted observations without overseas investment information (Wang \& Liu, 2021). Our final sample was an unbalanced panel, including a total of 10,141 firmyear observations for 1957 firms in 11 years.

\section{Variables}

\section{Dependent variable}

Following prior leads (Chang \& Rhee, 2011; Vermeulen \& Barkema, 2002; Yang et al., 2017), we measured the BRI investment speed by the cumulatively added number of OFDIs in the BRI destinations divided by the years since the beginning of the sampling period, i.e., the accumulated number of new BRI investments divided by the number of years since 2009. For one single firm, for instance, a firm that made the first investment in BRI countries in 2009 and then the second one in BRI countries in 2010, and its third BRI investments in 2012 created a BRI investment speed score of 1 in 2009 and 2010 and 0.75 in 2012. To identify countries that can be counted as a BRI investment, we 
applied the list of BRI countries at the end of 2019 referring to the official website (Belt \& Road Portal, 2020), which includes 62 countries.

\section{Independent variables}

Because we hypothesized comparative effects before and after the launch of the BRI policy, we introduced a dummy variable that equals 1 if the observations fall into the after-BRI period (20142019) and 0 otherwise (2009-2013). We then interacted this dummy with state equity and industry competition to construct the two primary predicting variables. Specifically, state equity is measured by the exact percentage of shares owned by the government or its agencies in the focal firm in a single year (Zhou et al., 2017). In parallel, industry competition is operationalized by the HerfindahlHirschman Index (HHI), which is calculated by the sum of the squares of each firm's market share competing in a focal industry sector (Krishnan, Joshi \& Krishnan, 2004). Notably, the HHI varies based on the firm's industry belonging in the focal year, and industry competition is weaker when the HHI is higher, meaning market concentration is higher. Thus, we expect the coefficient of $\mathrm{HHI}$ to be opposite to that of industry competition, as we hypothesized. We used the main industry classification categorized by the China Securities Regulatory Commission (CSRC), including utilities, properties, commerce, industrials, and conglomerates.

\section{Moderator}

$B R I$ province reflects the subnational support endowed by the central government. Referring to the policy scripts presented by the central government of China (Belt \& Road Portal, 2020), this variable is measured by a dummy variable that equals 1 for firms located in the 18 BRI-participating provinces because they obtain special support under the BRI theme and 0 otherwise. We then multiplied this dummy with the primary predicting variables to construct the moderating effects of the geographic aspects of the BRI.

\section{Control variables}

We further accounted for a batch of firm- and institution-level factors that might influence the speed of OFDIs to BRI destinations. First, firm age was included and measured by the natural logarithm of the number of years since founding (Bai et al., 2021; Kumar et al., 2020; Luo \& Wang, 2012).
We have also incorporated firm size as a control variable to account for organizational attributes that are related to speed decisions, which is measured by the natural logarithm of total assets in the corresponding year (Gaba et al., 2002; Liu \& Wang, 2020). Given that intangible assets such as reputation can also influence internationalization (Wang \& Liu, 2021), we further controlled goodwill by the natural logarithm of the firm's annual goodwill value, which is measured by the summation of the difference between the purchase price and the sum of the net fair value of focal assets under each merger and acquisition (Henning et al., 2000). Moreover, $R \& D$ expense, reflecting innovation capabilities, was controlled by the natural logarithm of the amount of a firm's research and development investment in a certain year (Wang \& Liu, 2021). We also controlled each firm's international experience, which is measured by the total number of foreign investment events in the prior year (Buckley et al., 2007; Wang et al., 2021). This figure captures the previous organizational degree of engagement in international markets and thus the level of experience (Gaba et al., 2002).

With respect to macro disturbances, we first introduced the provincial annual GDP growth rate to reflect economic health in a given province, which might influence the speed of international entry (Wang \& Liu, 2021). Moreover, firms located in provinces that are more open to international trade might have greater incentives to pursue aggressive BRI participation. Therefore, we controlled the provincial annual international trade degree with the natural logarithm of the overall value of exports and imports (Sjöholm, 1999).

\section{MODEL}

Because state equity for one typical firm rarely changes, we adopted random-effect regression models, which allow us to control for unobserved heterogeneity across firms and capture firm variations (Balakrishnan \& Fox, 1993). Our analysis is based on the following descriptive models:

$$
\begin{aligned}
\text { Speed }_{i, t}= & \alpha_{i}+\beta_{1} \mathrm{SE}_{i, t} \times \mathrm{BRIPo}_{i, t}+\beta_{2} \mathrm{SE}_{i, t}+\beta_{3} \mathrm{BRIPo}_{i, t} \\
& +\beta_{4} \mathrm{CV}_{i, t}+\varepsilon_{i, t}
\end{aligned}
$$

Speed $_{i, t}=\alpha_{i}+\beta_{1} I C_{i, t} \times \mathrm{BRIPo}_{i, t}+\beta_{2} \mathrm{IC}_{i, t}+\beta_{3} \mathrm{BRIPo}_{i, t}$

$$
+\beta_{4} \mathrm{CV}_{i, t}+\varepsilon_{i, t}
$$




$$
\begin{aligned}
\text { Speed }_{i, t}= & \alpha_{i}+\beta_{1} \mathrm{BRIPr}_{i, t} \times \mathrm{SE}_{i, t} \times \mathrm{BRIPO}_{i, t}+\beta_{2} \mathrm{BRIPr}_{i, t} \times \mathrm{SE}_{i, t} \\
& +\beta_{3} \mathrm{BRIPr}_{i, t} \times \mathrm{BRIPo}_{i, t}+\beta_{4} \mathrm{SE}_{i, t} \times \mathrm{BRIPO}_{i, t}+\beta_{5} \mathrm{BRIPr}_{i, t} \\
& +\beta_{6} \mathrm{SE}_{i, t}+\beta_{7} \mathrm{BRIPo}_{i, t}+\beta_{8} \mathrm{CV}_{i, t}+\varepsilon_{i, t}
\end{aligned}
$$

$$
\begin{aligned}
\text { Speed }_{i, t}= & \alpha_{i}+\beta_{1} \mathrm{BRIPr}_{i, t} \times \mathrm{IC}_{i, t} \times \mathrm{BRIPO}_{i, t}+\beta_{2} \mathrm{BRIPr}_{i, t} \times \mathrm{IC}_{i, t} \\
& +\beta_{3} \mathrm{BRIPr}_{i, t} \times \mathrm{BRIPo}_{i, t}+\beta_{4} \mathrm{IC}_{i, t} \times \mathrm{BRIPO}_{i, t}+\beta_{5} \mathrm{BRIPr}_{i, t} \\
& +\beta_{6} \mathrm{IC}_{i, t}+\beta_{7} \mathrm{BRIPo}_{i, t}+\beta_{8} \mathrm{CV}_{i, t}+\varepsilon_{i, t}
\end{aligned}
$$

where Speed $_{i, t}$ is our dependent variable of BRI investment speed for firm i in year $\mathrm{t}, \mathrm{SE}_{i, t}$ and $\mathrm{IC}_{i, t}$ reflect state equity and industry competition, $\mathrm{BRIPo}_{i, t}$ captures the temporal impacts of BRI policy, BRIPr ${ }_{i, t}$ indicates the key BRI-participating province, $\mathrm{CV}_{i, t}$ represents the bundle of our control variables, $\alpha_{i}$ captures the random firm effect, and $\varepsilon_{i, t}$ is the random error term. In Eqs. (1) and (2), our major interests are the two-way interaction coefficients of $\beta_{1}$, while the emphases are the three-way interaction coefficients of $\beta_{1}$ in Eqs. (3) and (4).

\section{RESULTS}

Table 2 presents descriptive statistics and correlations. Most correlations are less than 0.5, and the largest variance inflation factor (VIF) is 1.32, indicating that multicollinearity is not a major concern.

Table 3 reports the regression results. We included all the control variables in Model 1 and then hierarchically introduced the single terms of state equity, industry competition, BRI policy, and BRI province in Model 2, the primary predicting variables (i.e., two-way interaction terms) in Models 3 and 4 , and finally the geographic interaction terms (i.e., three-way interaction terms) in Models 5 and 6.

In Model 1, we found that firms with a larger size $(b=.068, p<.01)$ and greater international experience $(b=.005, p<.01)$ invest more quickly along the BRI routes, consistent with findings of the speed of OFDIs from the U.S. to China (Gaba et al., 2002).

Although we hypothesized comparative effects before and after the BRI policy, it is worth checking the general effects of state equity and industry competition across the entire sampling period. Intriguingly, as shown in Model 2, we found that firms with higher state equity expanded into BRI destinations more quickly between 2009 and 2019 $(b=.030, p<.10)$, as they should acknowledge

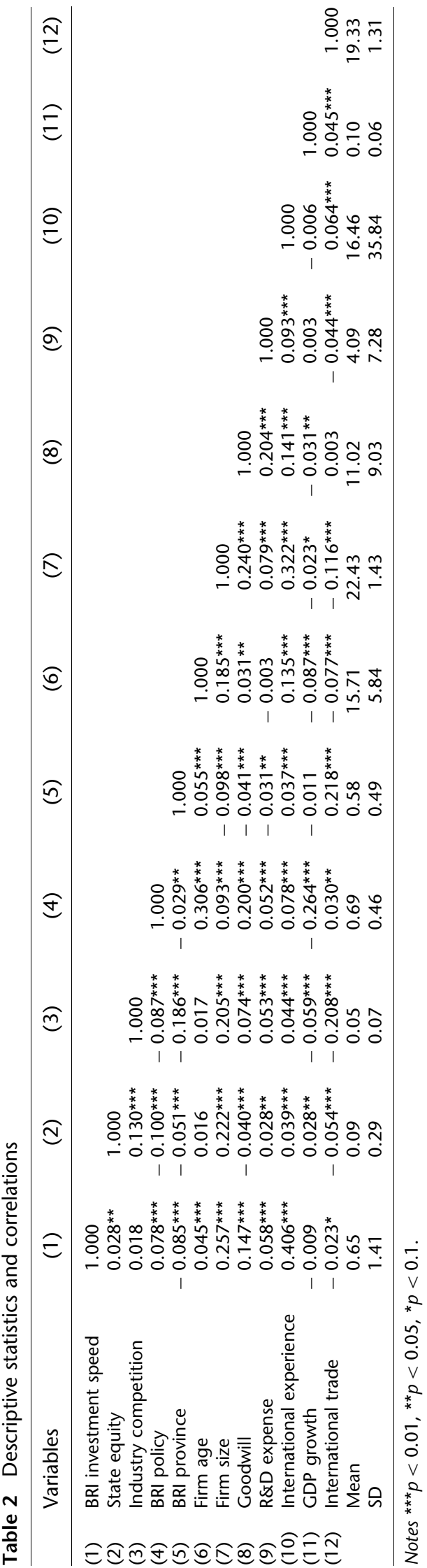


Table 3 Results of panel random-effect model

\begin{tabular}{|c|c|c|c|c|c|c|c|}
\hline Variables & & Model 1 & Model 2 & Model 3 & Model 4 & Model 5 & Model 6 \\
\hline \multicolumn{8}{|l|}{ Control variables } \\
\hline Firm age & & $\begin{array}{l}0.011 \\
(0.014)\end{array}$ & $\begin{array}{l}0.002 \\
(0.015)\end{array}$ & $\begin{array}{l}0.005 \\
(0.015)\end{array}$ & $\begin{array}{l}0.002 \\
(0.015)\end{array}$ & $\begin{array}{l}0.005 \\
(0.015)\end{array}$ & $\begin{array}{l}0.007 \\
(0.015)\end{array}$ \\
\hline Firm size & & $\begin{array}{l}0.068^{* * *} \\
(0.005)\end{array}$ & $\begin{array}{l}0.067^{* \star *} \\
(0.005)\end{array}$ & $\begin{array}{l}0.067^{* * *} \\
(0.005)\end{array}$ & $\begin{array}{l}0.068^{* * *} \\
(0.005)\end{array}$ & $\begin{array}{l}0.067^{* * *} \\
(0.005)\end{array}$ & $\begin{array}{l}0.067^{* \star *} \\
(0.005)\end{array}$ \\
\hline Goodwill & & $\begin{array}{l}0.003^{\star * *} \\
(0.000)\end{array}$ & $\begin{array}{l}0.003^{* * *} \\
(0.000)\end{array}$ & $\begin{array}{l}0.003^{* * *} \\
(0.000)\end{array}$ & $\begin{array}{l}0.002^{* * *} \\
(0.000)\end{array}$ & $\begin{array}{l}0.003^{* * *} \\
(0.000)\end{array}$ & $\begin{array}{l}0.002^{* * *} \\
(0.000)\end{array}$ \\
\hline$R \& D$ expense & & $\begin{array}{l}0.001 \\
(0.001)\end{array}$ & $\begin{array}{l}0.001 \\
(0.001)\end{array}$ & $\begin{array}{l}0.001 \\
(0.001)\end{array}$ & $\begin{array}{l}0.001 \\
(0.001)\end{array}$ & $\begin{array}{l}0.001 \\
(0.001)\end{array}$ & $\begin{array}{l}0.001 \\
(0.001)\end{array}$ \\
\hline International experience & & $\begin{array}{l}0.005^{\star * *} \\
(0.000)\end{array}$ & $\begin{array}{l}0.004^{\star * *} \\
(0.000)\end{array}$ & $\begin{array}{l}0.004^{* * *} \\
(0.000)\end{array}$ & $\begin{array}{l}0.004^{* * *} \\
(0.000)\end{array}$ & $\begin{array}{l}0.005^{\star * *} \\
(0.000)\end{array}$ & $\begin{array}{l}0.004^{* * *} \\
(0.000)\end{array}$ \\
\hline GDP growth & & $\begin{array}{l}0.014^{\star * *} \\
(0.002)\end{array}$ & $\begin{array}{l}0.013^{* * *} \\
(0.002)\end{array}$ & $\begin{array}{l}0.013^{* * *} \\
(0.002)\end{array}$ & $\begin{array}{l}0.014^{* \star *} \\
(0.002)\end{array}$ & $\begin{array}{l}0.013^{* * *} \\
(0.002)\end{array}$ & $\begin{array}{l}0.015^{* * *} \\
(0.002)\end{array}$ \\
\hline International trade & & $\begin{array}{l}-0.015^{\star *} \\
(0.007)\end{array}$ & $\begin{array}{l}-0.015^{* *} \\
(0.007)\end{array}$ & $\begin{array}{l}-0.014^{\star *} \\
(0.007)\end{array}$ & $\begin{array}{l}-0.017^{* *} \\
(0.007)\end{array}$ & $\begin{array}{l}-0.014^{\star *} \\
(0.007)\end{array}$ & $\begin{array}{l}-0.023^{* * *} \\
(0.007)\end{array}$ \\
\hline \multicolumn{8}{|l|}{ Main effects } \\
\hline State equity (SE) & & & $\begin{array}{l}0.030^{*} \\
(0.015)\end{array}$ & $\begin{array}{l}0.075^{* * *} \\
(0.019)\end{array}$ & $\begin{array}{l}0.027^{*} \\
(0.015)\end{array}$ & $\begin{array}{l}0.072^{* * *} \\
(0.028)\end{array}$ & $\begin{array}{l}0.028^{*} \\
(0.015)\end{array}$ \\
\hline Industry competition (IC) & & & $\begin{array}{l}-0.027^{\star \star *} \\
(0.009)\end{array}$ & $\begin{array}{l}-0.026^{* * *} \\
(0.009)\end{array}$ & $\begin{array}{l}-0.011 \\
(0.010)\end{array}$ & $\begin{array}{l}-0.026^{* * *} \\
(0.009)\end{array}$ & $\begin{array}{l}0.018 \\
(0.013)\end{array}$ \\
\hline BRI policy (BRIPo) & & & $\begin{array}{l}0.010 \\
(0.008)\end{array}$ & $\begin{array}{l}0.018^{\star *} \\
(0.008)\end{array}$ & $\begin{array}{l}-0.077^{\star \star \star} \\
(0.023)\end{array}$ & $\begin{array}{l}0.023^{* *} \\
(0.011)\end{array}$ & $\begin{array}{l}-0.167^{\star \star \star \star} \\
(0.031)\end{array}$ \\
\hline BRI province (BRIPr) & & & $\begin{array}{l}-0.043^{* *} \\
(0.018)\end{array}$ & $\begin{array}{l}-0.044^{\star *} \\
(0.018)\end{array}$ & $\begin{array}{l}-0.042^{* *} \\
(0.018)\end{array}$ & $\begin{array}{l}-0.032 \\
(0.020)\end{array}$ & $\begin{array}{l}-0.238^{* * *} \\
(0.068)\end{array}$ \\
\hline \multicolumn{8}{|l|}{ Interaction effects } \\
\hline $\mathrm{BRIPO} \times \mathrm{SE}$ & $\mathrm{H} 1$ & & & $\begin{array}{l}-0.094^{\star * *} \\
(0.024)\end{array}$ & & $\begin{array}{l}-0.026 \\
(0.035)\end{array}$ & \\
\hline BRIPo $\times$ IC & $\mathrm{H} 2$ & & & & $\begin{array}{l}-0.025^{\star \star *} \\
(0.006)\end{array}$ & & $\begin{array}{l}-0.057^{* * *} \\
(0.009)\end{array}$ \\
\hline $\mathrm{BRIPo} \times \mathrm{BRIPr} \times \mathrm{SE}$ & $\mathrm{H} 3 \mathrm{a}$ & & & & & $\begin{array}{l}-0.135^{* \star *} \\
(0.048)\end{array}$ & \\
\hline BRIPo $\times$ BRIPr $\times I C$ & $\mathrm{H} 3 \mathrm{~b}$ & & & & & & $\begin{array}{l}0.063^{* * *} \\
(0.013)\end{array}$ \\
\hline $\mathrm{BRIPo} \times \mathrm{BRIPr}$ & & & & & & $\begin{array}{l}-0.007 \\
(0.012)\end{array}$ & $\begin{array}{l}0.186^{* * *} \\
(0.045)\end{array}$ \\
\hline $\mathrm{BRIPr} \times \mathrm{SE}$ & & & & & & $\begin{array}{l}0.006 \\
(0.038)\end{array}$ & \\
\hline $\mathrm{BRIPr} \times \mathrm{IC}$ & & & & & & & 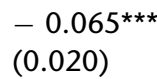 \\
\hline Constant & & $\begin{array}{l}-1.154^{\star * *} \\
(0.173)\end{array}$ & $\begin{array}{l}-1.184^{* * *} \\
(0.174)\end{array}$ & $\begin{array}{l}-1.208^{* * *} \\
(0.174)\end{array}$ & $\begin{array}{l}-1.096^{\star \star \star} \\
(0.175)\end{array}$ & $\begin{array}{l}-1.216^{\star \star \star} \\
(0.174)\end{array}$ & $\begin{array}{l}-0.927^{\star \star \star} \\
(0.182)\end{array}$ \\
\hline Observations & & 10,141 & 10,141 & 10,141 & 10,141 & 10,141 & 10,141 \\
\hline Number of listed firms & & 1957 & 1957 & 1957 & 1957 & 1957 & 1957 \\
\hline Chi-squared & & 2761 & 2784 & 2804 & 2806 & 2821 & 2845 \\
\hline
\end{tabular}

Notes Standard errors in parentheses

${ }^{* * *} p<0.01,{ }^{* *} p<0.05,{ }^{*} p<0.1$.

such participation as an important political agenda (Wang \& Liu, 2021). In parallel, we found that industry competition significantly facilitates the speed of BRI investment, given that the coefficient of HHI is significantly negative $(b=-.027, p<.01)$ throughout the entire sampling period.
Hypothesis 1 proposes that firms with greater state equity tend to invest more quickly along the BRI routes, particularly after the launch of the BRI. Referring to Model 3, the interaction term between state equity and BRI policy is negative and significant $(b=-.094, p<.01)$, in contrast to Hypothesis 1 . This result suggests that firms with greater 

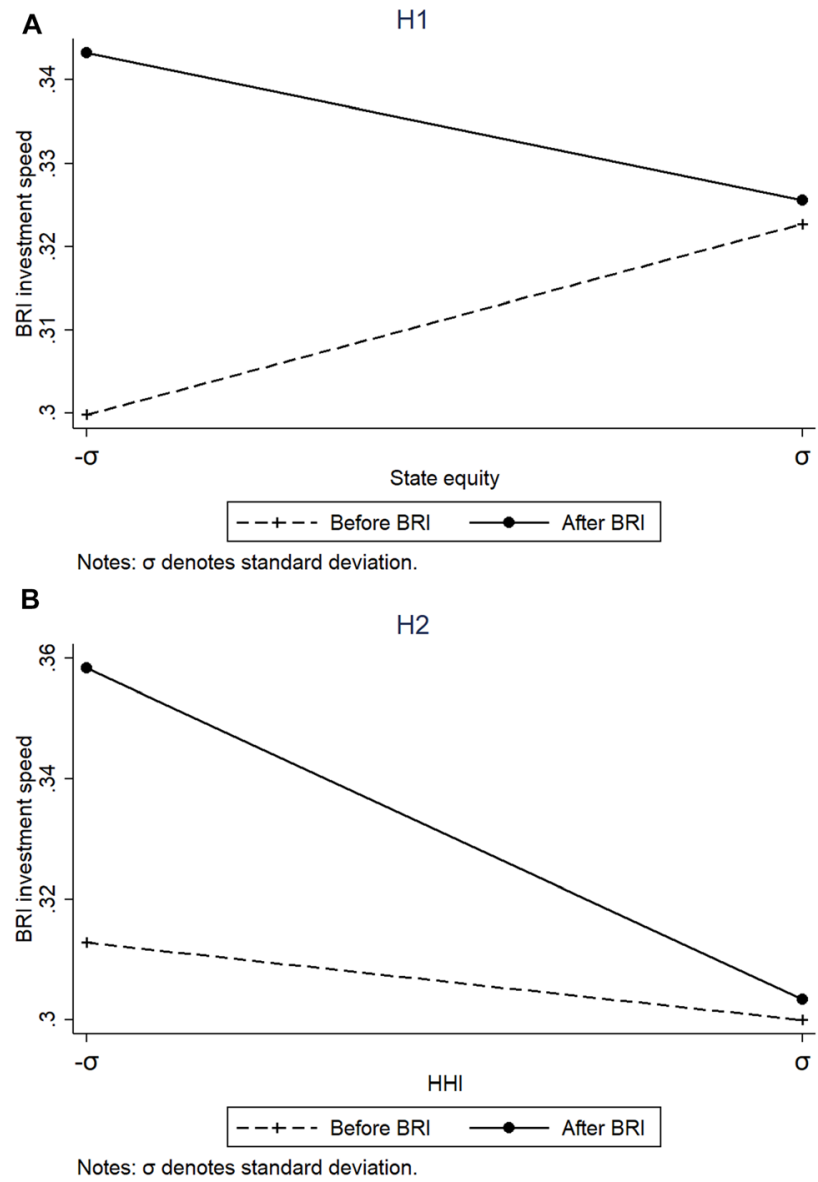

Figure 2 The moderating effect of BRI policy.

state equity are slow to invest in BRI markets, particularly after the launch of the BRI. Figure $2 \mathrm{a}$ and our marginal analysis further confirm that state equity is positively related to the speed of investing in BRI countries before the BRI $(b=.050, p<.01)$, but the effect becomes negative $(b=-.039$, $p<.10)$ after the launch of the BRI. This result may imply that firms with more state equity have a lower speed of internationalization under the BRI theme, albeit they used to be the first movers in the past. Thus, H1 is not supported.

Hypothesis 2 posits that firms under greater industry competition tend to invest more quickly along the BRI routes, particularly after the launch of the BRI. As expected, Model 4 reveals that the negative relationship between the HHI and speed of OFDIs to BRI destinations becomes stronger after the launch of the BRI $(b=-.025, p<.01)$, in support of H2. As Figure $2 b$ shows, the effect of the HHI is insignificant before $2013(b=-.007$, n.s.), but becomes significantly negative after 2013 $(b=-.030, p<.01)$. This result suggests that the launch of the BRI introduces new opportunities for firms to escape intense competition in home markets. Therefore, $\mathrm{H} 2$ receives strong support.

Hypothesis $3 a$ argues that firms with greater state equity and located in the planned key BRI-participating provinces tend to invest even more quickly in BRI destinations after 2013. As Model 5 shows, the three-way interaction among state equity, BRI policy, and BRI province is significantly negative $(b=-.135, p<.01)$. Figure $3 \mathrm{a}$ shows that the negative effect of the two-way interactions between state equity and BRI policy on the BRI investment speed becomes stronger when firms are located in BRI provinces. Contrary to the BRI blueprint, this finding suggests that firms with greater state equity do not take leading positions of investing in BRI destinations under the BRI theme, particularly for those located in the planned BRI-participating provinces. Therefore, H3a receives no support. This counterintuitive finding may reflect a rational 

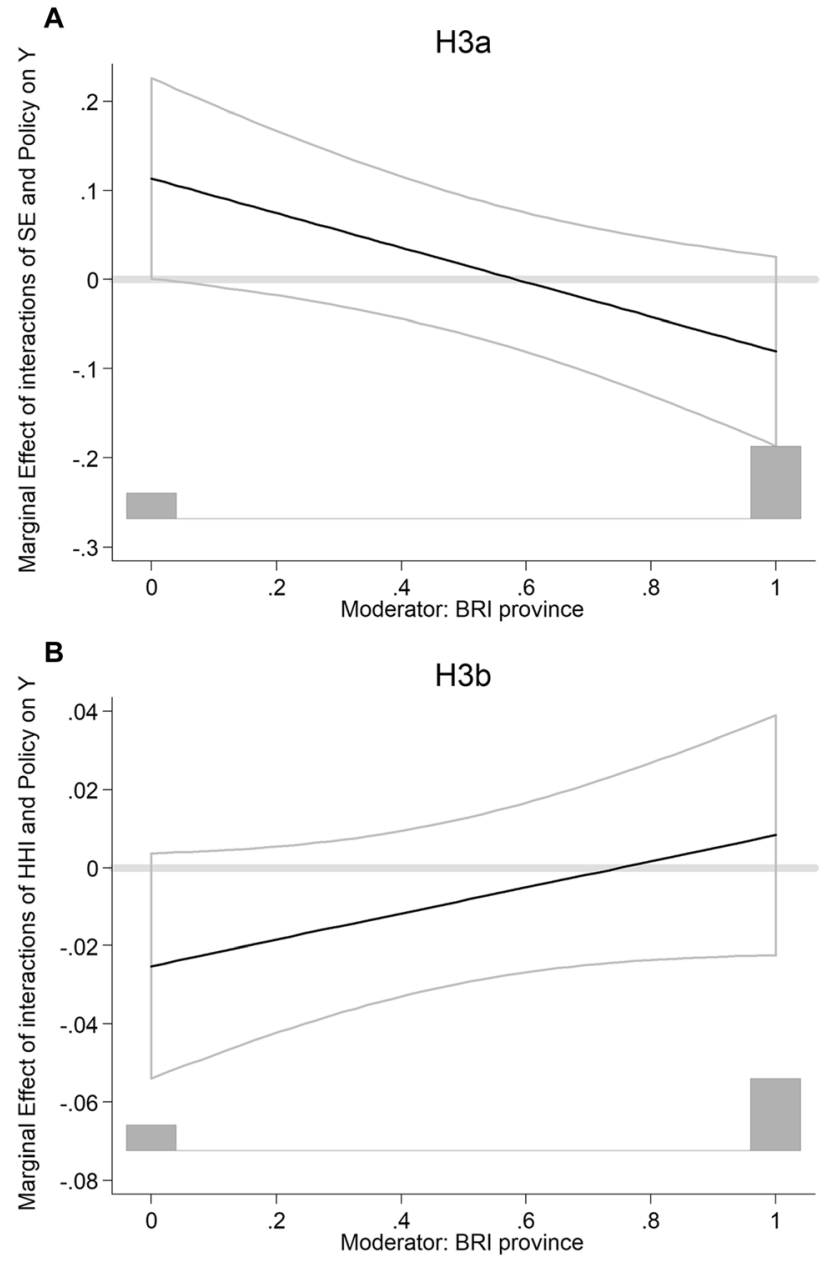

Figure 3 The moderating effect of BRI province.

calculation by firms. That is, firms with greater state equity might perceive favorable market conditions at home and thus become reluctant to expand quickly into risky BRI destinations, particularly when they receive special provincial support.

Hypothesis $3 \mathrm{~b}$ predicts that firms under greater industry competition and located in the planned BRI-participating provinces tend to invest even more quickly in BRI destinations after 2013. The three-way interaction of HHI, BRI policy, and BRI province in Model 6 is positive and significant $(b=.063, p<.01)$. Figure $3 \mathrm{~b}$ illustrates that the negative effect of the two-way interactions between the HHI and BRI policies on the BRI investment speed becomes weaker for firms located in BRI provinces. Thus, H3b is not supported. This finding may be due to the fact that the classification of BRI provinces is primarily based on their geographical positions without due consideration of the firms' capabilities. For instance, Heilongjiang Province, one of the planned BRI-participating provinces and neighbors with Russia, is designed as a central hub for economic cooperation with Russia under the BRI theme. However, firms in this province have weak capabilities of manufacturing light industrial products to match Russia's market demands.

\section{ROBUSTNESS TESTS}

We checked the robustness of our findings in several ways.

First, we substituted international experience with the number of years since the first time the firm has invested in any of the BRI destinations. We found that the direct effect of BRI experience is significant and positive $(b=.027, p<.01)$, and the results of our hypotheses tests remain highly consistent with our main tests. Specifically, the twoway interaction term between state equity and BRI policy is significantly negative $(b=-.059, p<.05)$, and the three-way interaction term of state equity, BRI policy and BRI province is still significantly negative $(b=-.101, p<.05)$. Additionally, the two-way interaction term between $\mathrm{HHI}$ and BRI policy is significantly negative $(b=-.028, p<.01)$, thus supporting $\mathrm{H} 2$, but such facilitative effects would be curbed when firms are located in BRI province $(b=.066, p<.01)$.

Second, we examined whether the unexpected effects of state equity are caused by heterogeneous levels of state influences. That is, firms without dominant control by the state may deviate from the political agenda and thus show slow gestures in investing along the BRI routes, obfuscating the results. Therefore, we created a dummy variable that equals 1 if state ownership is more than $50 \%$ in the focal firm, indicating dominant control, and 0 otherwise. We then retested Hypothesis 1 based on the interaction between this new variable and BRI policy but found a positive result $(b=.111$, $p>.10)$. Although insignificant, this finding implies that the government may push SOEs to invest largely under the BRI theme, but firms with greater state equity (not yet to be defined as SOEs) are generally reluctant to do so, which will be explained in the Discussion section.

Third, we used the number of listed firms in the same industry sector and region as an alternative operationalization of industry competition to validate its moderating effects (Liu \& Wang, 2020). This alternative (direct) measurement of industry competition positively affects the speed of investing in BRI countries $(b=.029, p<.01)$, and such 
effects become stronger after the launch of the BRI $(b=.022, p<.01)$. We also found that the threeway interaction term of industry competition, BRI policy, and BRI province is negative and significant $(b=-.060, p<.01)$, confirming the effects of industry competition and the ineffectiveness of the geographic aspect of the BRI. Thus, the results remain robust under this alternative measurement of industry competition.

Fourth, we lagged our independent variables to account for any potential possibilities that the predictors realized their effects in a longer period. We found that the new results of the two-way and three-way interaction terms are highly consistent with our prior findings. Specifically, the two-way interaction term between state equity and BRI policy is significantly negative $(b=-.094$, $p<.01$ ), while the two-way interaction term between HHI and BRI policy is significantly negative $(b=-.024, p<.01)$. Moreover, the three-way interaction of state equity, BRI policy and BRI province is still significantly negative $(b=-.138$, $p<.01)$, while the three-way interaction of HHI, BRI policy, and BRI province is still significantly positive $(b=.049, p<.01)$.

Although beyond our research scope, we have further explored whether our proposed mechanisms apply to the rhythm dimension of BRI investment. Analogous to the idea of turbulence that describes an object's chaotic changes, rhythm is defined as the regularity of international expansion that captures the distribution of the speed in a given period of time (Vermeulen \& Barkema, 2002). We applied the equation presented in the previous literature (Vermeulen \& Barkema, 2002: 644) and investigated whether our proposed mechanisms can be generalized to this different dimension: regular pattern, these statistics together suggest that escapism should be the main mechanism that explains the OFDIs from China to BRI countries within the sampling period.

\section{ADDITIONAL TESTS}

To investigate why planned key BRI-participating provinces do not demonstrate the expected policy effects, we conducted additional tests. One potential reason for these intriguing findings is that the planned key BRI-participating provinces include both coastal and inland provinces, where firms might present different capabilities in conducting OFDIs (Wang \& Liu, 2021). That is, most of the designed provinces are inland and poor in economies (Qian et al., 2018), so many of the local firms lack the necessary competencies to invest in the BRI destinations.

Therefore, we investigated the subnational differences by creating one dummy variable called inland province, which indicated whether the BRIparticipating province is an inland province or a coastal province. As shown in Table 4, the interaction term between state equity and BRI inland province is insignificant $(b=.006$, n.s.), whereas the interaction term between HHI and BRI inland province is significantly positive $(b=.094, p<.01)$. This finding indicates that the positive effect of industry competition under the BRI theme becomes weaker when firms are located in inland provinces. Given that all the planned BRI-participating provinces are provided with strong support from the central government while firms rationally desire less competitive markets, the difference is likely caused by the insufficient capabilities in capitalizing on the BRI policy for firms in those inland provinces. While the government may

$$
\text { kurtosis }(\text { rhythm })=\left\{\frac{n(n+1)}{(n-1)(n-2)(n-3)} \sum\left(\frac{x_{i}-\bar{x}}{s}\right)^{4}\right\}-\frac{3(n-1)^{2}}{(n-2)(n-3)}
$$

Pooling the observations together showed that the relationship between state equity and rhythm is insignificant $(b=-.024$, n.s. $)$, while the HHI positively affects the rhythm $(b=.043, p<.05)$. While indicating that firms under higher industry competition tend to expand into the BRI under a acknowledge that firms in those regions lag in the speed of internationalization and thus purposefully choose those as key provinces with the intention to boost economic development, our results show that the realization of this policy intention is less effective at the moment. 
Table 4 Additional tests

\begin{tabular}{|c|c|c|c|}
\hline Variables & Model 1 & Model 2 & Model 3 \\
\hline \multicolumn{4}{|l|}{ Control variables } \\
\hline Firm age & $\begin{array}{l}-0.008 \\
(0.019)\end{array}$ & $\begin{array}{l}-0.008 \\
(0.019)\end{array}$ & $\begin{array}{l}-0.010 \\
(0.019)\end{array}$ \\
\hline Firm size & $\begin{array}{l}0.066^{\star * *} \\
(0.007)\end{array}$ & $\begin{array}{l}0.066^{\star \star *} \\
(0.007)\end{array}$ & $\begin{array}{l}0.066^{* * *} \\
(0.007)\end{array}$ \\
\hline Goodwill & $\begin{array}{l}0.003^{\star * *} \\
(0.001)\end{array}$ & $\begin{array}{l}0.003^{\star * *} \\
(0.001)\end{array}$ & $\begin{array}{l}0.003^{* * *} \\
(0.001)\end{array}$ \\
\hline$R \& D$ expense & $\begin{array}{l}-0.000 \\
(0.001)\end{array}$ & $\begin{array}{l}-0.000 \\
(0.001)\end{array}$ & $\begin{array}{l}-0.000 \\
(0.001)\end{array}$ \\
\hline International experience & $\begin{array}{l}0.004^{* * *} \\
(0.000)\end{array}$ & $\begin{array}{l}0.004^{* * *} \\
(0.000)\end{array}$ & $\begin{array}{l}0.004^{* * *} \\
(0.000)\end{array}$ \\
\hline GDP growth & $\begin{array}{l}0.018^{\star * *} \\
(0.003)\end{array}$ & $\begin{array}{l}0.018^{* * *} \\
(0.003)\end{array}$ & $\begin{array}{l}0.018^{\star * *} \\
(0.003)\end{array}$ \\
\hline International trade & $\begin{array}{l}-0.029^{* \star *} \\
(0.011)\end{array}$ & $\begin{array}{l}-0.029^{* * *} \\
(0.011)\end{array}$ & $\begin{array}{l}-0.030^{* * *} \\
(0.011)\end{array}$ \\
\hline \multicolumn{4}{|l|}{ Main effects } \\
\hline State equity (SE) & $\begin{array}{l}0.005 \\
(0.021)\end{array}$ & $\begin{array}{l}0.004 \\
(0.023)\end{array}$ & $\begin{array}{l}0.006 \\
(0.021)\end{array}$ \\
\hline Industry competition (IC) & $\begin{array}{l}-0.048^{\star * *} \\
(0.012)\end{array}$ & $\begin{array}{l}-0.048^{\star \star \star} \\
(0.012)\end{array}$ & $\begin{array}{l}-0.062^{* \star *} \\
(0.013)\end{array}$ \\
\hline Inland city (Inland) & $\begin{array}{l}0.040 \\
(0.047)\end{array}$ & $\begin{array}{l}0.039 \\
(0.048)\end{array}$ & $\begin{array}{l}0.306^{\star \star \star} \\
(0.107)\end{array}$ \\
\hline \multicolumn{4}{|l|}{ Interaction effects } \\
\hline $\mathrm{SE} \times$ Inland & & $\begin{array}{l}0.006 \\
(0.055)\end{array}$ & \\
\hline IC $\times$ Inland & & & $\begin{array}{l}0.094^{\star * *} \\
(0.034)\end{array}$ \\
\hline Constant & $\begin{array}{l}-1.002^{\star * *} \\
(0.253)\end{array}$ & $\begin{array}{l}-1.002^{\star \star *} \\
(0.254)\end{array}$ & $\begin{array}{l}-1.032^{\star * *} \\
(0.253)\end{array}$ \\
\hline Observations & 5884 & 5884 & 5884 \\
\hline Number of listed firms & 1120 & 1120 & 1120 \\
\hline Chi- squared & 1577 & 1577 & 1586 \\
\hline
\end{tabular}

Notes Standard errors in parentheses

${ }^{* * *} p<0.01,{ }^{* *} p<0.05,{ }^{*} p<0.1$.

\section{DISCUSSION}

The study is among the first studies to address the lack of research on speed decisions of OFDIs under the BRI theme. It applies the push and pull antecedents of OFDIs simultaneously while investigating both temporal and geographic aspects of the policy. The fundamental motivation is to identify antecedents of the speed of OFDIs that are applicable to the BRI context while identifying any policy implications that are useful for policymakers. We approach the study by examining the speed of OFDIs made by publicly listed Chinese firms in BRI destinations.

Specifically, we found that industry competition drives faster BRI investments, particularly after the launch of the BRI. Contrary to our expectations, however, firms with greater state equity exhibit significant slow gestures in investing along the routes after the launch of the BRI, albeit they used to be the first movers in the past (i.e., before the launch of the BRI), and firms with more than 50\% state shares might be pushed to do so. Although it has been proposed that slow internationalization speed might be caused by rigidity in unlearning and time compression diseconomies in adaptation (Vermeulen \& Barkema, 2002), this situation may not be the case for the BRI context. To explain, firms with greater state equity performed better before the launch of the BRI, and their experience should be applicable to BRI destinations, given that most of them are emerging economies as well. Consequently, we speculate that the slow speed of firms with greater state equity reflects their prudence in participating in the BRI, which is not necessarily a bad thing. 
While confirming that the BRI per se is timewise significant, we unmasked that planned key BRIparticipating provinces do not generate the expected policy effects. Specifically, the facilitative effects of industry competition on the speed of OFDIs after the launch of the BRI are weaker for firms located in BRI-participating provinces, whereas firms with greater state equity are more reluctant when located in BRI-participating provinces. Referring to the additional tests, we further unveiled that those intriguing findings might be caused by an inadequate positioning of those planned BRI-participating provinces. Specifically, most of those provinces are inland poor provinces in which local firms lack the necessary competencies to invest in BRI destinations.

In summary, we respond to the calls for more examinations of the BRI (Li et al., 2019b; Wang \& Liu, 2021) and antecedents of the burgeoning OFDIs initiated from emerging economies (Lebedev et al., 2015). Several theoretical and policy implications are worth discussing further.

\section{THEORETICAL IMPLICATIONS}

First, we supplement the paucity of research on the speed decisions of internationalization. The speed of entry draws little attention in the IB literature yet matters much for the organizational competitive advantages in the international market (Chang \& Rhee, 2011; Gaba et al., 2002; Vermeulen \& Barkema, 2002), insofar as quick expansions could indicate either more market opportunities or higher risks (Luo \& Wang, 2012)

While corroborating the coherent positive effects of firm size and international experience, we unveiled diametrical determinants of the speed of OFDIs from emerging economies to emerging economies (cf., Gaba et al., 2002). We find that quick OFDIs are driven mainly by domestic industry competition. The BRI context has ensured the same starting line, as the destinations are new to nearly every participating firm. Although firms might accelerate their international expansions when the destination has a higher market size and poses lower national risks (Gaba et al., 2002), they all face the same growing potential and have limited references of competitors to follow in unknown markets. Because BRI markets are institutionally risky and few of the hosting regions would provide comparable support as China would, we can confidently argue that domestic industry competition drives firms' quick expansions into foreign markets, indicating that the escape (pull) mechanism dominates at least in the BRI context.

We also draw attention to the boundary condition of push and pull antecedents of OFDIs in the literature. While the extant literature emphasizes the benefits of obtaining state support in internationalization (Buckley et al., 2007), recent studies have started to recognize the efficiency losses caused by state equity (Qian et al., 2018; Zhou et al., 2017). We join this burgeoning theoretical conversation but further extend that the efficiency losses can come from other sources.

If participating in the BRI is aligned the political agenda (Wang \& Liu, 2021), it is difficult to claim that hesitation caused by state equity results from the divergence between political interests and economic interests (cf. Zhou et al., 2017). Instead, the slow speed might be caused by the reluctance to leave incumbent comfort zones. That is, faced with risky and uncertain foreign markets, firms with greater state equity are slow in diversifying internationally, as they may already possess favorable domestic market conditions (Tihanyi et al., 2019). We thus challenge the conventional wisdom of state equity and encourage further explorations of the ambidextrous effects of state equity in IB activities, particularly from emerging economies.

Finally, we highlighted subnational differences. Specifically, we add that those subnational resource endowments and institutional status make substantial differences under the BRI theme. These regional conditions can constitute critical references for organizational calculations when they intend to expand abroad. We urge IB studies to pay particular attention to such fine-grained differences, as most emerging economies are characterized by unequal regional developments (Qian et al., 2018).

\section{POLICY IMPLICATIONS}

First, we corroborate escapism as the main mechanism of the speed of OFDIs under the BRI theme. By juxtaposing the effects of state equity and industry competition, we suggest that Chinese firms generally hold conservative attitudes toward quick expansions to BRI destinations. Firms with greater state equity are not necessarily the first movers, albeit they have been expected to be pioneering players in the BRI. That is, the political push factors cannot facilitate BRI investment speed; instead, it is mainly economic pull factors that attract faster investment along the routes. 
The findings thus indicate that the traditional narrative of the BRI might be incomplete. We challenge the assumption that the BRI is another form of state capitalism driven by SOEs in industries with large excess capacity in China; rather, private firms and firms in highly competitive industries constitute the pioneers in investing along the BRI routes. While clarifying the nature of the BRI, these findings remind policy-makers to stop using their political power manifested in state equity to push firms to internationalize. Additionally, the government should restructure the performance evaluation criteria for investments in state equity to inspire quicker responses while placing more emphasis on private enterprises, particularly in competitive industries.

The findings also caution that different dimensions of OFDIs should be attributed to distinctive mechanisms (cf., Gaur et al., 2018), highlighting that different policies should be emphasized for different political agendas and goals. Particularly, the identified slow gesture of firms with greater state equity sends an important message to policymakers that they should select different policy instruments when they prioritize goals of either speeding up or increasing the scales of OFDIs.

Third, we advance the understanding of BRI policy. On the one hand, we ascertain that the BRI indeed changes the IB landscapes by comparing the differences between pre- and post-BRI periods (cf., Li et al., 2019b). Although it is too early to claim that the BRI has achieved its projected goals, the governmental officials along the BRI routes should adopt a more proactive stance toward this magnificent project.

On the other hand, our findings indicate that firms located in the most supported provinces are not serving as the leading pioneers under the BRI theme, although they possess historical ties with or geographic advantages to those BRI destinations. This finding rings the alarm that policy-makers should wisely consider the factor endowment of the location for initiating new policy-led projects such as the BRI and that the present policy support might be insufficient. Instead of providing subsidies at the province level, wise selections of the target companies are greatly needed.

\section{LIMITATIONS AND FUTURE EXTENSIONS}

Our study has a few limitations that can help direct future research. First, internationalization is a multidimensional construct, but we only focused on the speed dimension. That is, internationalization can take the forms of exporting or importing and FDIs or OFDIs, which could be measured either by scale, scope, speed, or rhythm. Although we clarified that our intention is to address the lack of research on the speed dimension, future studies can explore how the identified factors would influence different forms and aspects of internationalization. As such, we can present fine-grained instruments to manage BRI policies.

Second, we require samples from countries other than China. While we corroborated the policy effects of the BRI, our findings only provide one side of the story. It would be useful to examine the policy effects contextualized in other BRI countries; otherwise, it is difficult to claim that new trade routes and economic interdependency are successfully built. It would also be fruitful to generalize the findings to multiple-country samples, which could help identify nuanced institutional and cultural differences.

Third, it is unknown how mega-events and shocks influence the BRI. Although we controlled for institutional disturbances by year dummies, mega shocks such as the recent trade war between the United States and China and COVID-19 might reconfigure the development and plans of the BRI (Buckley, 2020; Van Assche \& Lundan, 2020). Examining the interactions between the BRI and external shocks should generate insightful policy implications.

\section{CONCLUSION}

In summary, the study invoked the push and pull antecedents of OFDIs to offer a systematic examination of omitted speed questions under the BRI theme. It provided additional understandings of the BRI and policy suggestions for policy-makers. While corroborating the policy effects of the BRI along the temporal dimension, it found that escapism is the main explanation of faster OFDIs under the BRI theme and that state equity does not help much, nor does the BRI realize its effects in the geographical aspect. This study serves as a modest initiative, and we encourage further explorations of different policy dimensions of the BRI and their antecedents.

\section{ACKNOWLEDGEMENTS}

We sincerely thank the acting editor Lee Li, the anonymous reviewers, and the editing team for their 
excellent suggestions. The earlier version of this paper has been presented at the Academy of International Business Annual Conference in 2019 and the Academy of International Business Southeast Asia Regional Conference in 2020. We thank the reviewers and participants for their valuable feedbacks. The work described was partially supported by the Fundamental Research Funds for the Central Universities in China [2072021126 and JBK21YJ48] and the National Natural Science Foundation of China [72102199 and 71872159].

\section{NOTES}

${ }^{1}$ These countries include nations such as Cambodia, Cyprus, Malaysia, Pakistan, and Tajikistan. The detailed list can be obtained from the official BRI site, retrieved on July 3, 2021, from https://www. yidaiyilu.gov.cn/gbjg/gbgk/77073.htm. Referring to our sampling time, we used the list of BRI countries at the end of 2019.

${ }^{2}$ These provinces include Chongqing, Fujian, Gansu, Guangdong, Guangxi, Hainan,

\section{REFERENCES}

Bai, X., Wang, Q., Sheng, S., \& Li, J. J. 2021. Cross-level interpersonal ties and IJV innovation: Evidence from China. Journal of Business Research, 134: 618-630.

Balakrishnan, S., \& Fox, I. 1993. Asset specificity, firm heterogeneity and capital structure. Strategic Management Journal, 14: 3-16.

Belt and Road Portal. 2017. Combing the blueprint of the Belt and Road Initiative [in Chinese]. Retrieved May 7, 2020, from https://www.yidaiyilu.gov.cn/ztindex.htm.

Belt and Road Portal. 2020. List of countries that have signed Belt and Road Initiative cooperation document with China [in Chinese]. Retrieved May 8, 2020, from https://www.yidaiyilu. gov.cn/gbjg/gbgk/77073.htm.

Buckley, P. J. 2020. China's Belt and Road Initiative and the COVID-19 crisis. Journal of International Business Policy, 3(3): $311-314$.

Buckley, P. J., Clegg, J., Cross, A. R., Liu, X., Voss, H., \& Zheng, P. 2007. The determinants of Chinese outward foreign direct investment. Journal of International Business Studies, 38(4): 499-518.

Chang, A., Torres de Oliveira, R., Chung, H.M., \& Zheng, N. forthcoming. Subnational response differences on the Belt and Road Initiative policy and firm internationalization: A longitudinal and multi-level approach. Journal of International Business Policy.

Chang, S. J., \& Rhee, J. H. 2011. Rapid FDI expansion and firm performance. Journal of International Business Studies, 42(8): 979-994.

Du, J., \& Zhang, Y. 2018. Does One Belt One Road Initiative promote Chinese overseas direct investment? China Economic Review, 47: 189-205.

Gaba, V., Pan, Y., \& Ungson, G. R. 2002. Timing of entry in international market: An empirical study of US Fortune 500 firms in China. Journal of International Business Studies, 33(1): 39-55.
Heilongjiang, Jilin, Liaoning, Neimenggu, Ningxia, Qinghai, Shanghai, Shanxi, Xinjiang, Xizang, Yunnan, and Zhejiang.

${ }^{3}$ See the provincial governmental website as a reference (in Chinese): http://www.gansu.gov.cn/ art/2017/1/19/art_35_298138.html [Accessed on Dec 20, 2020].

${ }^{4}$ At the end of 2019 , countries that officially signed the memorandums and/or agreements to join the BRI, i.e., BRI countries, are located in the Middle East (15 countries), Eastern Europe including Russia (10), other parts of Europe (10), Southeast Asia (9), South Asia (10), Central Asia (5), and East Africa (3).

${ }^{5}$ Industry competition varies based on the organizational industry belonging in each year.

${ }^{6}$ We sincerely thank the anonymous reviewers and the editors for their excellent recommendations in robustness tests. Due to space limitations, the results are available upon request.

${ }^{7}$ We give special thanks to one reviewer for suggesting this insightful dimension.

Gao, G. Y., Murray, J. Y., Kotabe, M., \& Lu, J. 2010. A "strategy tripod" perspective on export behaviors: Evidence from domestic and foreign firms based in an emerging economy. Journal of International Business Studies, 41(3): 377-396.

Gaur, A. S., Ma, X., \& Ding, Z. 2018. Home country supportiveness/unfavorableness and outward foreign direct investment from China. Journal of International Business Studies, 49(3): 324-345.

Greve, H. R., \& Zhang, M. C. 2017. Institutional logics and power sources: Merger and acquisition decisions. Academy of Management Journal, 60(2): 671-694.

Gurin, N., How, P.D.S., Jackson, S.A., \& Yu, P.N. 2015. How significant are the security and political risks and threats to China's grand westward strategy in Central Asia? University of Hong Kong Libraries.

Henning, S. L., Lewis, B. L., \& Shaw, W. H. 2000. Valuation of the components of purchased goodwill. Journal of Accounting Research, 38(2): 375-386.

Johanson, J., \& Vahlne, J. E. 2009. The Uppsala internationalization process model revisited: From liability of foreignness to liability of outsidership. Journal of International Business Studies, 40(9): 1411-1431.

Krishnan, R. A., Joshi, S., \& Krishnan, H. 2004. The influence of mergers on firms' product-mix strategies. Strategic Management Journal, 25: 587-611.

Kumar, V., Singh, D., Purkayastha, A., Popli, M., \& Gaur, A. 2020. Springboard internationalization by emerging market firms: Speed of first cross-border acquisition. Journal of International Business Studies, 51(2): 172-193.

Lebedev, S., Peng, M. W., Xie, E., \& Stevens, C. E. 2015. Mergers and acquisitions in and out of emerging economies. Journal of World Business, 50(4): 651-662.

Li, J., Li, P., \& Wang, B. 2019a. The liability of opaqueness: State ownership and the likelihood of deal completion in 
international acquisitions by Chinese firms. Strategic Management Journal, 40(2): 303-327.

Li, J., Liu, B., \& Qian, G. 2019b. The Belt and Road Initiative, cultural friction and ethnicity: Their effects on the export performance of SMEs in China. Journal of World Business, 54(4): 350-359.

Li, J., Qian, G., Zhou, K. Z., Lu, J., \& Liu, B. 2021a. Belt and Road Initiative, globalization and institutional changes: Implications for firms in Asia. Asia Pacific Journal of Management. https:// doi.org/10.1007/s10490-021-09770-0.

Li, J., Van Assche, A., Li, L., \& Qian, G. 2021b. Foreign direct investment along the Belt and Road: A political economy perspective. Journal of International Business Studies. https:// doi.org/10.1057/s41267-021-00435-0.

Liu, B., \& Wang, Q. 2020. Can certification help incumbent firms? Asia Pacific Journal of Management, 37: 1061-1083.

Luo, Y., \& Wang, S. L. 2012. Foreign direct investment strategies by developing: Country multinationals: A diagnostic model for home country effects. Global Strategy Journal, 2(3): 244-261.

Peng, M. W., Wang, D. Y., \& Jiang, Y. 2008. An institution-based view of international business strategy: A focus on emerging economies. Journal of International Business Studies, 39(5): 920-936.

Porter, M. E. 1980. Competitive strategy: techniques for analyzing industries and competitors. New York: The Free Press: 1980.

Qian, G., Li, L., \& Rugman, A. M. 2013. Liability of country foreignness and liability of regional foreignness: Their effects on geographic diversification and firm performance. Journal of International Business Studies, 44(6): 635-647.

Qian, G., Liu, B., \& Wang, Q. 2018. Government subsidies, state ownership, regulatory infrastructure, and the import of strategic resources: Evidence from China. Multinational Business Review, 26(4): 319-336.

Sjöholm, F. 1999. Exports, imports and productivity: Results from Indonesian establishment data. World Development, 27(4): 705-715.

Tang, R. W. 2019. FDI expansion speed of state-owned enterprises and the moderating role of market capitalism: Evidence from China. International Business Review, 28(6): 113.

Tihanyi, L., Aguilera, R. V., Heugens, P., van Essen, M., Sauerwald, S., Duran, P., \& Turturea, R. 2019. State ownership and political connections. Journal of Management, 45(6): 2293-2321.

Van Assche, A. 2018. From the editor: Steering a policy turn in international business - opportunities and challenges. Journal of International Business Policy, 1: 117-127.

Van Assche, A., \& Lundan, S. 2020. From the editor: COVID-19 and international business policy. Journal of International Business Policy, 3: 273-279.

Vermeulen, F., \& Barkema, H. 2002. Pace, rhythm, and scope: Process dependence in building a profitable multinational corporation. Strategic Management Journal, 23(7): 637-653.

Wang, P., Jiang, X., \& Dong, M. C. 2021. Alliance experience and performance outcomes: A meta-analysis. Strategic Organization. https://doi.org/10.1177/1476127020982875.
Wang, P., Ma, Y., \& Hu, Z. 2018. Unraveling the effect of alliance experience on alliance formation and alliance governance structure: A meta-analytic approach. Australian Journal of Management, 43(4): 653-671.

Wang, Q., \& Liu, B. 2021. State equity and outward FDI under the theme of Belt and Road Initiative. Asia Pacific Journal of Management. https://doi.org/10.1007/s10490-020-09716-y.

Wang, Q., Xie, X., \& Wang, M. 2015. Environmental regulation and firm location choice in China. China Economic Journal, 8(3): 215-234.

World Bank. 2012. China Trade Summary 2012 Data. Retrieved May 12, 2020, from https://wits.worldbank.org/ CountryProfile/en/Country/CHN/Year/2012/Summary.

Yang, J. Y., Lu, J., \& Jiang, R. 2017. Too slow or too fast? Speed of FDI expansions, industry globalization, and firm performance. Long Range Planning, 50: 74-92.

Zhou, K. Z., Gao, G. Y., \& Zhao, H. 2017. State ownership and firm innovation in China: An integrated view of institutional and efficiency logics. Administrative Science Quarterly, 62(2): 375-404.

\section{ABOUT THE AUTHORS}

Bin Liu (PhD, Chinese University of Hong Kong) is Assistant Professor at Xiamen University. His research interests are international business, corporate governance, and family business. He is one of the leading pioneers in investigating the Belt and Road Initiative in the international business domain. He has published research articles in journals such as Asia Pacific Journal of Management, Journal of World Business, and Multinational Business Review, etc.

Qingtao Wang (PhD, City University of Hong Kong) is Lecturer at Southwest University of Finance and Economics. His current research interests include digital marketing strategy and international marketing in the context of "One Belt and One Road" initiatives. He has published at referred journals such as Asia Pacific Journal of Management, China Economic Journal, Journal of Business Research, Multinational Business Review, etc.

Publisher's Note Springer Nature remains neutral with regard to jurisdictional claims in published maps and institutional affiliations.

Accepted by Lee Li, Guest Editor, 15 October 2021. This article has been with the authors for six revisions. 